\title{
THE IMPACT OF ACCIDENT RISK MANAGEMENT IN AN ENTERPRISE DEALING WITH SCRAP PROCESSING AND COLLECTION WITH THE USE OF A SPAGHETTI DIAGRAM
}

\author{
Artur Woźny ${ }^{1}$, Michał Kościółek², Anna Ostrowska-Dankiewicz ${ }^{3}$ Piotr Saja ${ }^{4}$ \\ ${ }^{1,2,3}$ Rzeszów University of Technology, Aleja Powstańców Warszawy 12, 35-959 Rzeszów, Poland \\ ${ }^{4}$ Podkarpackie Centre for Teaching Services, Rymanowska 15a, 35-083 Rzeszów, Poland

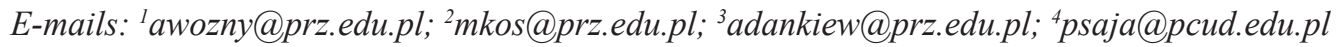

Received 10 August 2021; accepted 11 October 2021; published 30 December 2021

\begin{abstract}
Company management is associated with a number of activities. Occupational health and safety management is one of these activities. Taking care of proper health and safety is not only the responsibility of an employer, but also significantly contributes to the quality and efficiency of work. The subject of this paper is an example of occupational health and safety management in the aspect of accident risk management on the example of a scrap metal collection and processing company. In the paper the use of the Spaghetti diagram to improve safety in the workplace was presented.
\end{abstract}

Keywords: management; occupational health and safety management; accident procedure; Spaghetti diagram

Reference to this paper should be made as follows: Woźny, A., Kościółek, M., Ostrowska-Dankiewicz, A., Saja, P. 2021. The impact of accident risk management in an enterprise dealing with scrap processing and collection with the use of a Spaghetti Diagram. Journal of Security and Sustainability Issues, 11, 497-507. https://doi.org/10.47459/jssi.2021.11.45

JEL Classifications: I12

Additional disciplines: safety

\section{Introduction}

Company management is associated with the implementation of specific short and long-term goals. Profit achievement is not the only goal of the company's operations. An ability to survive, function or develop depends on many factors which often exist only in individual industries. The specificity of managing a given enterprise depends on its size and type of activity. Therefore, specialized human resources allow one to effectively achieve the goals of the company.

Regardless of the company's activity profile, there are constant elements that every company must have. One talks about proper management of occupational health and safety (OSH). The company's operation cannot be effective if safety issues are not sufficiently cared for (Woźny, Dobosz, 2015; Bernardi, 2019).

\section{Occupational health and safety management in an enterprise}

Occupational health and safety is an activity of a company that aims to protect an employee against an undesirable event, i.e. an accident at work. Therefore, through their internal activities, enterprises create a health and safety culture, which is the result of group and individual attitudes, values, competences, behaviors and quality of management. Hence, the health and safety culture reflects the attitude of employees to hazards, risks and their potential consequences. Properly managed human resources determine the OSH culture. Therefore, it is mainly 
up to an employer and the managerial staff how the safety culture in the enterprise develops (Studenski, 1996).

The culture of occupational health and safety is the sum of three components: barriers, education and risk. Barriers should be understood as all activities aimed at eliminating or reducing the employee's exposure to a given hazard or reducing the effects of a potential undesirable event. The installation of anti-slip mats on external stairs is an example of eliminating the effects of a potential threat. Education is the level of awareness and knowledge of employees in the general scope of occupational health and safety and in the detailed scope covering the specificity of the working environment (Woźny, Saja, Dobosz, 2018).

The Constitution of the Republic of Poland is basic legal act in Poland that provides for safe and hygienic working conditions. In art. 66 the right of every employee are guaranteed.

Art. 24. The work is under the protection of the Republic of Poland. The state supervises the conditions of work performance.

Art. 66. Everyone has the right to safe and healthy working conditions. The way of exercising this right and the obligations of the employer are specified in the Act.

Art. 68. Everyone has the right to health protection (The Constitution of the Republic of Poland).

There are a number of related laws and regulations in Polish legislation with broadly understood work safety. Figure 1 shows the legal basis and regulations related to health and safety which are important in building a safety management system in an enterprise.

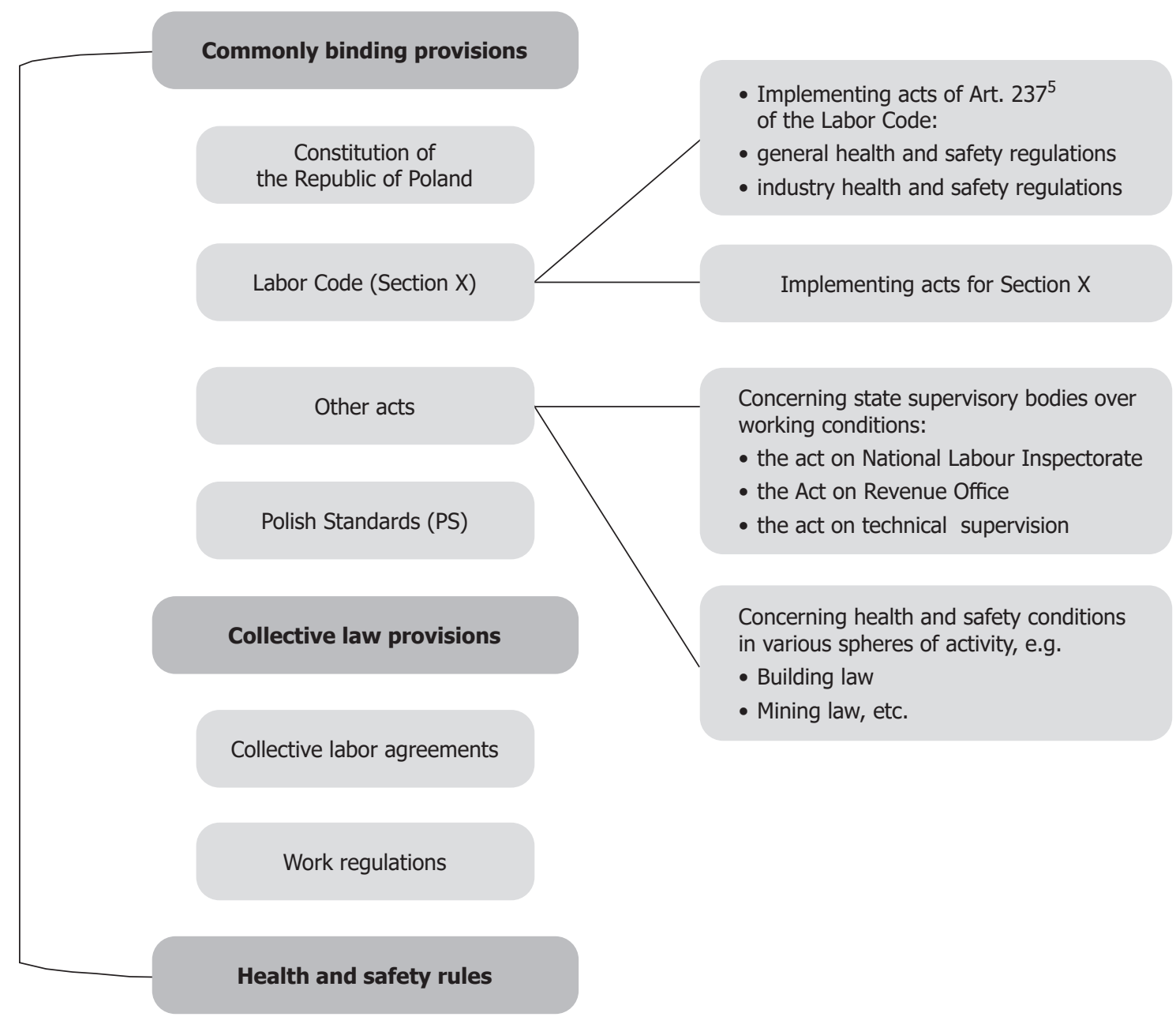

Figure 1. Legal basis on health and safety 
Legal regulations indicate a number of tasks that an entrepreneur (employer) must fulfill to ensure safe working environment. It is worth emphasizing that the mere fulfillment of the requirements set by normative acts, industry standards, etc., does not guarantee complete safety. Safety management is a continuous process in a company. From the point of view of creating a safety culture, it is important that an entrepreneur:

- is aware that safe working environment is a guarantee of quality

- and efficiency,

- knows the legal basis and standards for the organization of safe work,

- has appropriate procedures in the event of a crisis situation,

- is aware of the occupational risk at individual work positions,

- creates work culture and cooperate with the health and safety service.

The role of an employee is to:

- be aware of the risks existing at the workplace,

- feel safe at the workplace,

- participate in the creation and promotion of safety culture,

- use the machines and devices available to them in a safe and consistent manner

- according to instructions and procedures,

- report any irregularities that can be removed (Woźny, 2020).

Although an employer is responsible for the health and safety at work, the desired state in this respect is created by all units included in a given enterprise.

Safety management should primarily be understood as a specific managerial activity that focuses on the quality aspects of the work environment, which must guarantee safety in every element (people, machines, processes, etc.). It is extremely important when the individual management functions (planning, organizing, controlling, motivating) are taken into account. When planning and setting goals, management should define safety plans and goals that will motivate action. Therefore, the safety management functions are related to:

- Planning safe work environment,

- Organizing the system or processes taking into account health and safety,

- Motivating in the field of health and safety,

- Health and safety control.

This approach makes quality the most important element in decision-making by management. Health and safety management is mainly characterized by:

- focus on an employee and the internal environment of a company by ensuring the best level of security,

- a systemic approach, each safety-related activity can be recreated at any time,

- impact on human and material resources, as each process which takes place in an enterprise is supported by appropriate health and safety conditions,

- involvement of all employees and management in related matters with occupational health and safety,

- creating a health and safety culture,

- documenting all activities related to health and safety (Woźny, Pacana, 2017).

Such a general approach to security management makes a systemic approach to management possible in every enterprise. Through the proper functioning of the interconnected subsystems, it is possible to create such conditions of the working environment that create space for a qualitative approach to issues related to safe and hygienic working conditions. 


\section{Accident risk management}

Skillful OHS management enables the reduction or elimination of an important factor that is relevant for shaping the quality and efficiency of work. It is about loss, lost opportunities or resources that have an impact on the functioning of an enterprise. The occurrence of a loss determines specific behaviors not only in an employer, but also in an employee, which makes it difficult to properly motivate to work. Improper management of an enterprise including occupational health and safety management may result in:

- material losses,

- losses related to the adverse health effects of employees,

- other losses depending on the negative consequences arising in an enterprise.

It is in the employer's interest to prevent losses in an enterprise. Therefore, the employer should have a health and safety service that supports them in proper safety management. However, it happens that the interpretation of the company's protection against loss is different. In principle, risk is an inseparable element of the activity of every enterprise regardless of the country or industry. Managers knowledge and competences that will allow them to efficiently deal with the risk in the company are necessary to be able to conduct business in an undisturbed way (Dankiewicz R, Ostrowska-Dankiewicz A., Bulut C., 2020). In most cases, the employer perceives losses through the economic prism. The functioning health and safety service understands protection against loss as a safe working environment. Differences in the perception of loss confirm that the OHS service plays an important role in the enterprise. Figure 2 shows the types of losses that can arise as a result of the employer's inappropriate approach to safety issues and occupational hygiene (Główczyńska-Woelke, 2009)

Woźny (2015) et al. in their research indicated the influence of management on quality and work efficiency. The authors of the paper changed the approach of A. Maslow's pyramid of needs and confronted them with the needs of an enterprise. According to A. Maslow, in order to meet the needs of a higher order (affiliation, respect and recognition as well as self-fulfillment), it is necessary to ensure the needs of a lower order (physiological and security). Through the prism of the labor needs pyramid, lower-order needs can be understood as the need to have a job (physiological need). Each unit signs an employment contract and enters into an employment relationship with an employer. The status of an employee determines the next level of the labor needs pyramid, namely the need for security. The role of an employer is to meet the requirements specified by the Labor Code (Woźny, Pacana, Dobosz, Saja, 2015) (see Figure 2).

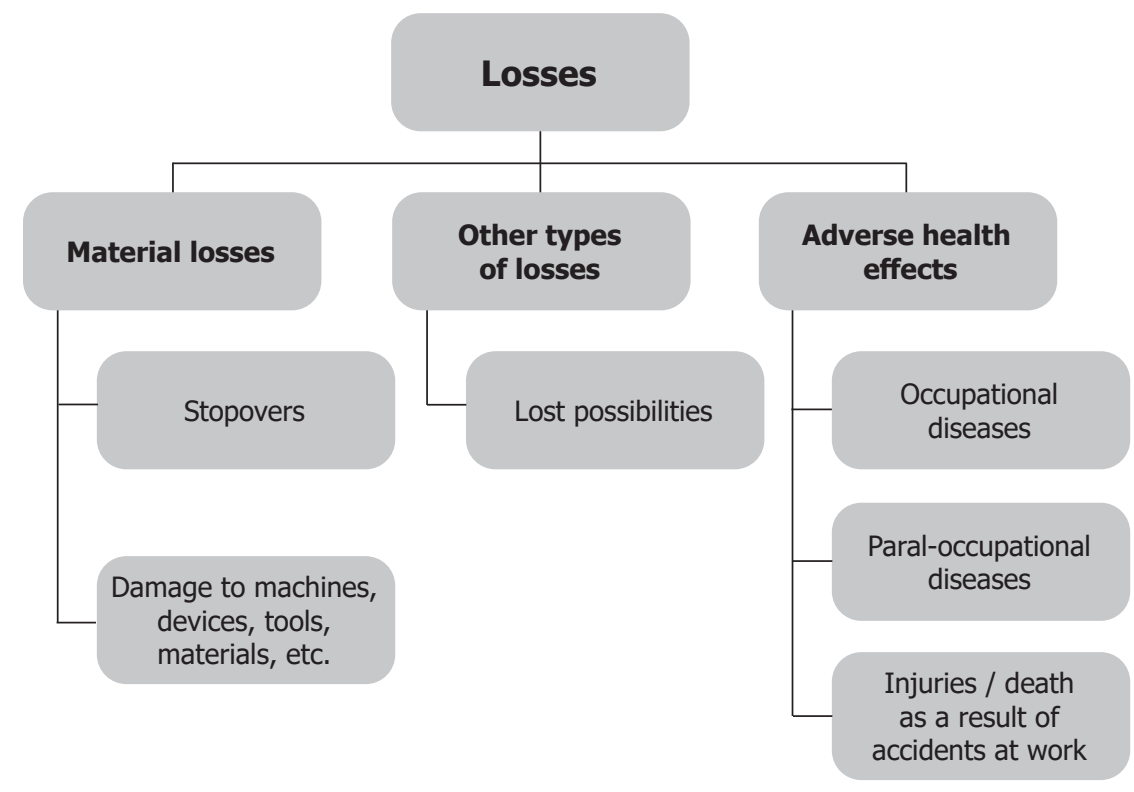

Figure 2. Losses that may arise through improper OHS management. 
Pursuant to Art. 3.1 of the Act of October 30, 2002 on social insurance due to accidents at work and occupational diseases (Journal of Laws of 2019, item 1205), an accident at work is a sudden event caused by an external cause, making injury or death which occurred in connection with work. In this situation, an employer has to start the post-accident procedure by appointing a commission in which an employer may:

- employee representative,

- health and safety inspector,

- social labor inspector,

- occupational physician,

- the employer himself.

Regulation of the Council of Ministers of July 1, 2009 on establishing circumstances and causes of accidents at work (Journal of Laws of 2009, No. 105, item 870) in $\S 2$ indicates that an employee who has suffered an accident, if their health condition allows it, should immediately inform their supervisor about the accident. Such action is aimed at launching the post-accident procedure. The employer or supervisor, for example, by an appropriate order, appoints an accident commission, which is to determine the circumstances and cause of the event. The tasks of the commission are clearly defined:

- perform an inspection of the accident site, the technical condition of machines and other technical devices, the condition of protective devices and the conditions of work

- and other circumstances that could have an impact on the accident;

- if necessary, sketch or take a photograph of the accident scene;

- listen to the explanations of the injured person, if their state of health allows it;

- gather information about the accident from bystanders of the accident;

- consult a doctor and, if necessary, the opinion of other specialists, to the extent necessary to assess the type and consequences of the accident;

- collect other evidence about the accident;

- make a legal classification of the accident in accordance with Art. $3 \mathrm{sec} .1$ and 2 of the Act of 30 October 2002 on social insurance against accidents at work and occupational diseases (Journal of Laws No. 199, item 1673 , as amended), define preventive measures and conclusions, in particular resulting from the occupational risk assessment at the workplace where the accident occurred.

After determining the circumstances and causes of the accident, the post-accident team draws up - no later than within 14 days from the date of receipt of the notification of the accident - a protocol establishing the circumstances and causes of the accident at work, hereinafter referred to as the "accident report", according to the template established by the minister responsible for work on pursuant to Art. $237 \S 2$ of the Act of June 26, 1974 - the Labor Code.

The general guidelines for the accident procedure are clearly defined in applicable regulations. However, it is worth paying attention to the scheme of action that should apply when analyzing the causes and potential effects of accidents. It is worth paying attention to a simple scheme related to reporting an accident (Woźny, Saja, Dobosz, 2019). (see Figure 3). 


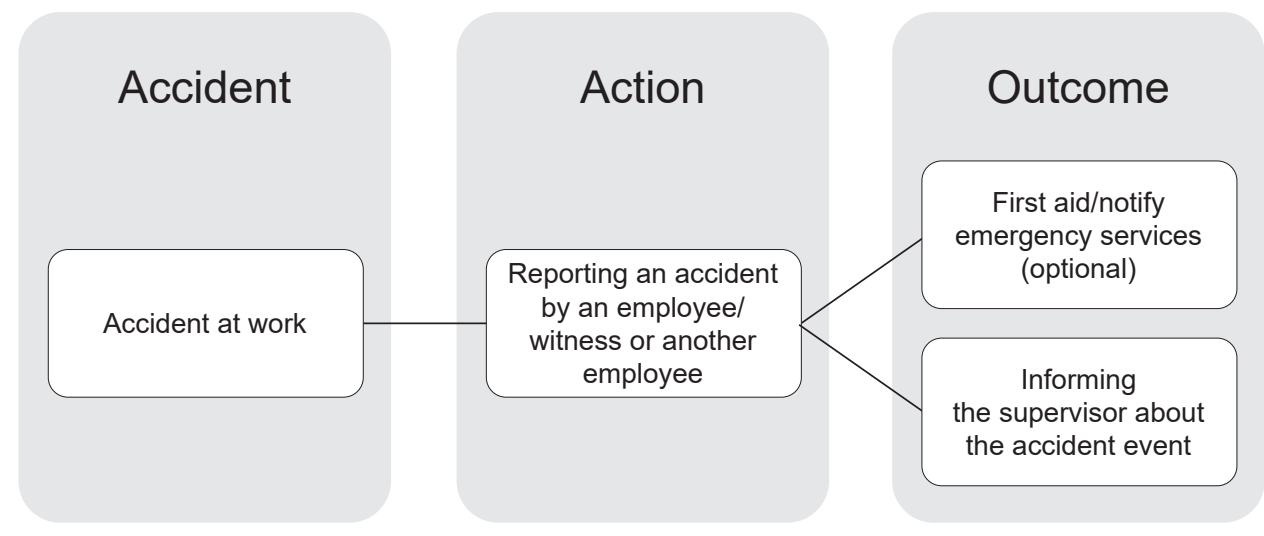

Figure 3. Scheme of reporting an accident.

Source: Woźny A., Saja P., Dobosz M., Zapobieganie błędom w procedurze powypadkowej z wykorzystaniem diagramu przyczynowo-skutkowego Ishikawy, [in:] Praktyczne aspekty zarządzania produkcją i bezpieczeństwem, red. R. Ulewicz, R. Dwornicka, Wyd. Wydawnictwo Politechniki Krakowskiej, Kraków 2019.

One should note that in the case of the accident procedure, the scheme of action is much more extensive. Upon reporting the accident, an employer appoints an accident commission whose task is to analyze the causes of the accident and to carry out the entire procedure. The task of the commission is to analyze the scene of the incident, collect explanations from the victim and witnesses of the incident. At the stage of collecting information, the medical documents received by the injured person from the family doctor or from a hospital emergency department. On the basis of the data received, it is possible to prepare an accident protocol, adequate to the current situation.

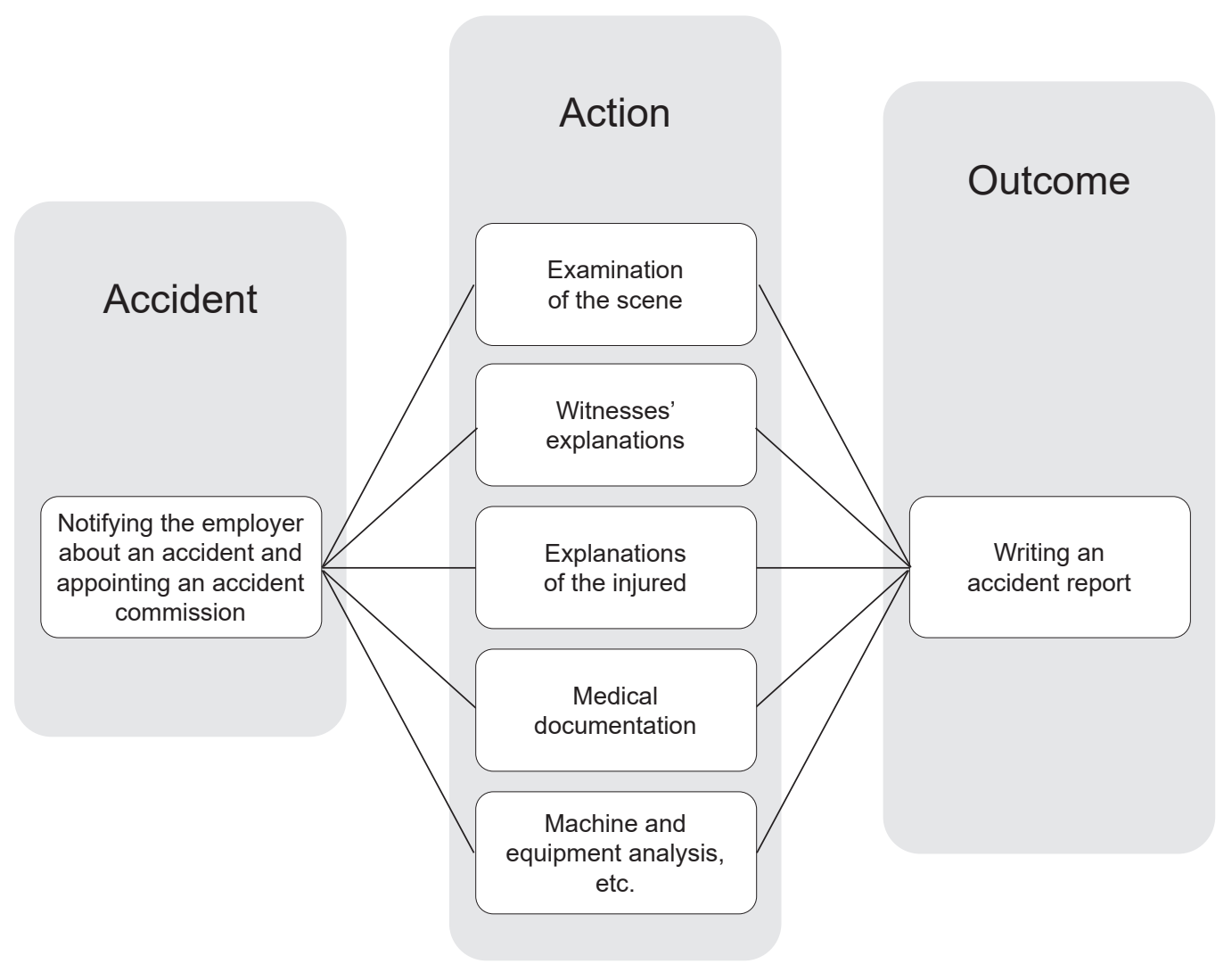

Figure 4. Scheme of the post-accident procedure. 
The very process of reporting an accident involves significantly fewer activities than in the case of the implementation of the post-accident procedure itself. The number of activities carried out by the post-accident team may cause a number of errors that can significantly extend the time needed to write the post-accident report. It should be pointed out that it is the properly constructed system or the OHS culture that determines how the information about an accident event will proceed. The reaction of the injured person, other employees, and in particular the management and the employer is crucial not only for the health and life of the accident participant at work, but also for the post-accident procedure carried out in terms of determining the causes and circumstances (Woźny, Saja, Dobosz, 2019).

\section{Accident risk management using the Spaghetti diagram}

It is an employer's duty to organize safe and hygienic working environment conditions. It is also designed to counteract threats and prevent accidents at work. It is possible through the implementation of various types of procedures and the proper organization of OHS by:

- Appropriate employee training (initial and periodic training) and on-the-job instructors,

- Worked out occupational risk,

- Health and safety instructions for machines and devices,

- Health and safety instructions for specific positions and work processes,

- Other procedures, handling, etc.

However, it is worth emphasizing that sometimes the procedures implemented are not sufficient and an accident at work will occur. The case under the analysis took place in a scrap metal collection and processing company. Due to the specificity of the enterprise, it occupies a 2-hectare square with various buildings (office, warehouse, production, etc.). Between the given objects, there are designated places for a specific type of raw material (colored scrap, steel, rubber, etc.), which, depending on a given process, is processed on a specialized machine. Usually it involves grinding, fractioning and then pressing or briquetting the material, which then goes to steel mills and other plants using the finished material. On one of the site related to the processing of colorful scrap the accident happened.

The employee in the position of a scrap sorter-machine operator started work on the second shift, where usually there were few employees who are located at different positions and in variousplaces on the plant site. According to the work assignment, he operated an aluminum briquetting press. The work consisted in controlling the efficiency and continuity of the device's operation as, well as taking the finished briquette out of the hopper and putting it into a container bag. At some point, the device stopped automatically because the detector detected that there was too much chip in the briquetting press's piston. The employee first activated the safety button, the so-called the emergency mushroom switched off the machine in order to remove the excess aluminum chips. After performing this activity, in accordance with the procedure and OHS instructions, the employee continued working, but the briquetting press blocked again for a longer time. Then, for unknown reasons, an employee operating the device wrapped a cloth on his hand and put it in the piston in order to remove the excess aluminum shavings. At the moment when the employee was removing the excess material, the detector released itself and grabbed the employee's hand. As a result of the movement of the piston of the machine, the workers' fingers were crushed. The worker, freeing his bleeding arm, wanted to go to the supervisor assigned for that day, to provide him with first aid and to call the ambulance.

As a result of the incident 2 fingers of the right hand were amputated. In connection with the serious incident, an internal control and the control by the National Labor Inspectorate were initiated on the premises of the workplace. As a result of the accident investigation and control activities both the employee and the employer were found to be guilty for the incident. In particular, it was noted that the employee:

- did not comply with the internal health and safety regulations,

- did not apply the procedure in the event of the device being immobilized,

- performed an improper cleaning of the device without the knowledge and consent of the supervisor. 
As a result of the inspection, it was also indicated that the employer:

- on the day of the incident, did not have a sufficient number of employees (foremen, managers) who supervised the employees,

- the injured party did not know where and to whom to go after the accident incident on the second shift where the number of employees was smaller,

- did not inform the employee about the procedure in the event of an accident, and did not inform the employee who was appointed to provide first aid.

The use of the Spaghetti diagram allowed for the analysis of the path followed by the injured employee from the moment of the accident to first aid being provided to him by the person managing the employees on that day on the second shift. A diagram (or a graph) of spaghetti is a tool that allows you to observe the path of a product / service (or employee) through the area of its implementation. The first step in making a spaghetti diagram is getting a scale plant plan. The person or group of employees responsible for the creation analyzes the production path of the product. It's a great help to be able to follow him physically. Then the path of the product is plotted on the plan. The last step is to analyze the diagram carefully. Figure 4 shows the path followed by the injured person.

The use of the Spaghetti diagram allowed making the analysis of the way followed by the injured employee from the moment of the accident to first aid being provided to him by the person managing the employees on that day on the second shift. A diagram (or a graph) of spaghetti is a tool that allows observing the path of a product/ a service (or an employee) through the area of its implementation. The first step in making a spaghetti diagram is to get a scale plant plan. The person or a group of employees responsible for the creation analyzes the production path of the product. It's a great help to be able to follow him physically. Then the path of the product is plotted on the plan. The last step is to analyze the diagram carefully (Figure 5).

It should be noted that after the incident, the injured employee went through virtually all facilities on the premises of the plant before finding the person managing the employees on that day in order to provide first aid. The employee was not aware of where to go in the event of an accident and did not know the place where first aid kits are located.

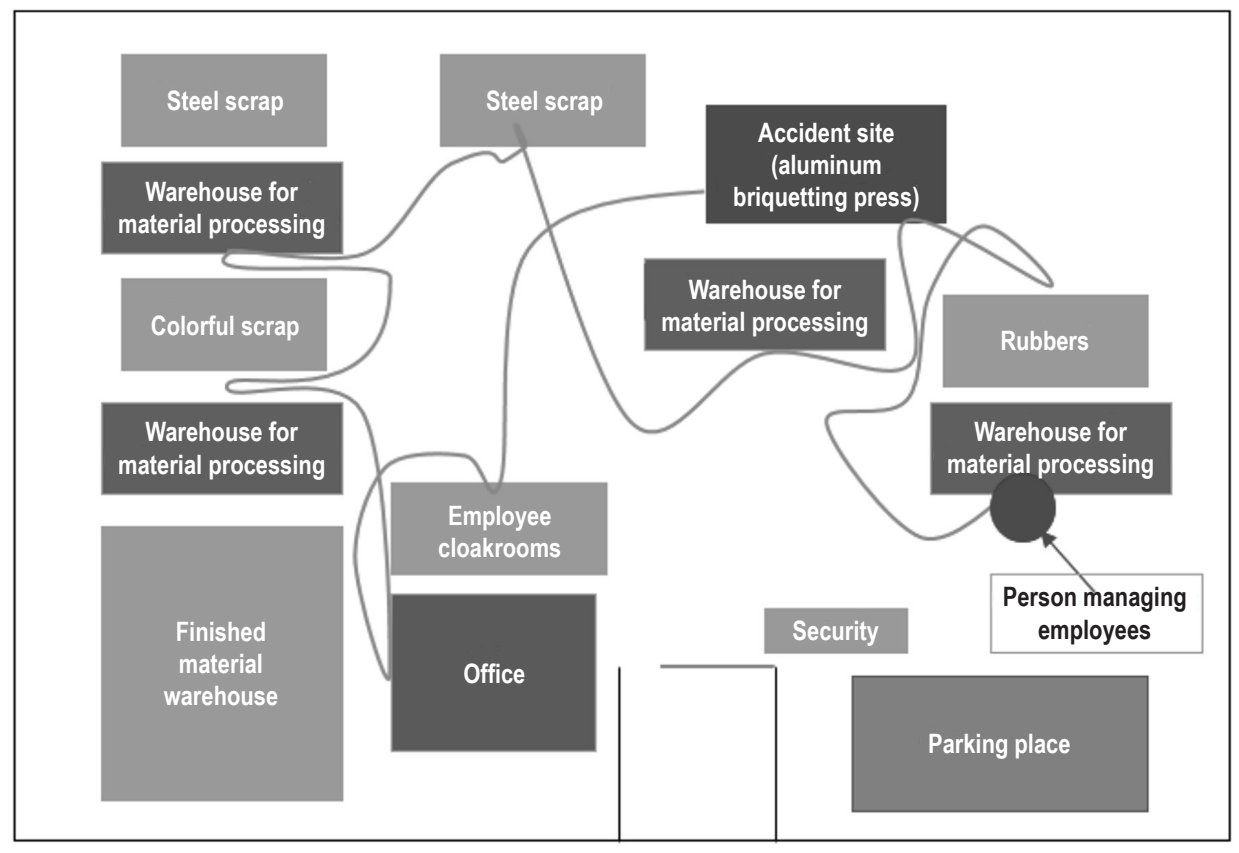

Figure 5. Spaghetti Diagram - the injured party's path from the scene to the person in charge who provided first aid and notified the medical services. 
Due to the lack of sufficient protection of the workplace against the negative effects of accidents, external institutions partially relegated the responsibility for the incident to the employer and managers. As a result of the inspection and an analysis of the entire event, from its inception to first aid, corrective actions were taken. An analysis of the Spaghetti diagram revealed the path the injured worker had taken before he was given some treatment. Therefore, one of the corrective and preventive elements include the design of first aid places where employees can go in the event of an accident. At the facilities located on the main communication routes, some space was organized where:

- there is a first aid kit,

- instructions with pictograms regarding first aid,

- emergency numbers are indicated, including the number for persons responsible for providing first aid,

- a first aid button, where the manager receives a message on the business phone about the incident and location, is installed,

- an appropriately marked place.

Due to the specificity of the workplace, space and distance between individual buildings, such action seems the most rational from the point of view of efficiency and speed in response. After proposing changes, the path of the casualty to the supervisor or the person providing first aid will significantly decrease. The casualty can choose from several places that guarantee quick assistance. This is shown in figure 6 .

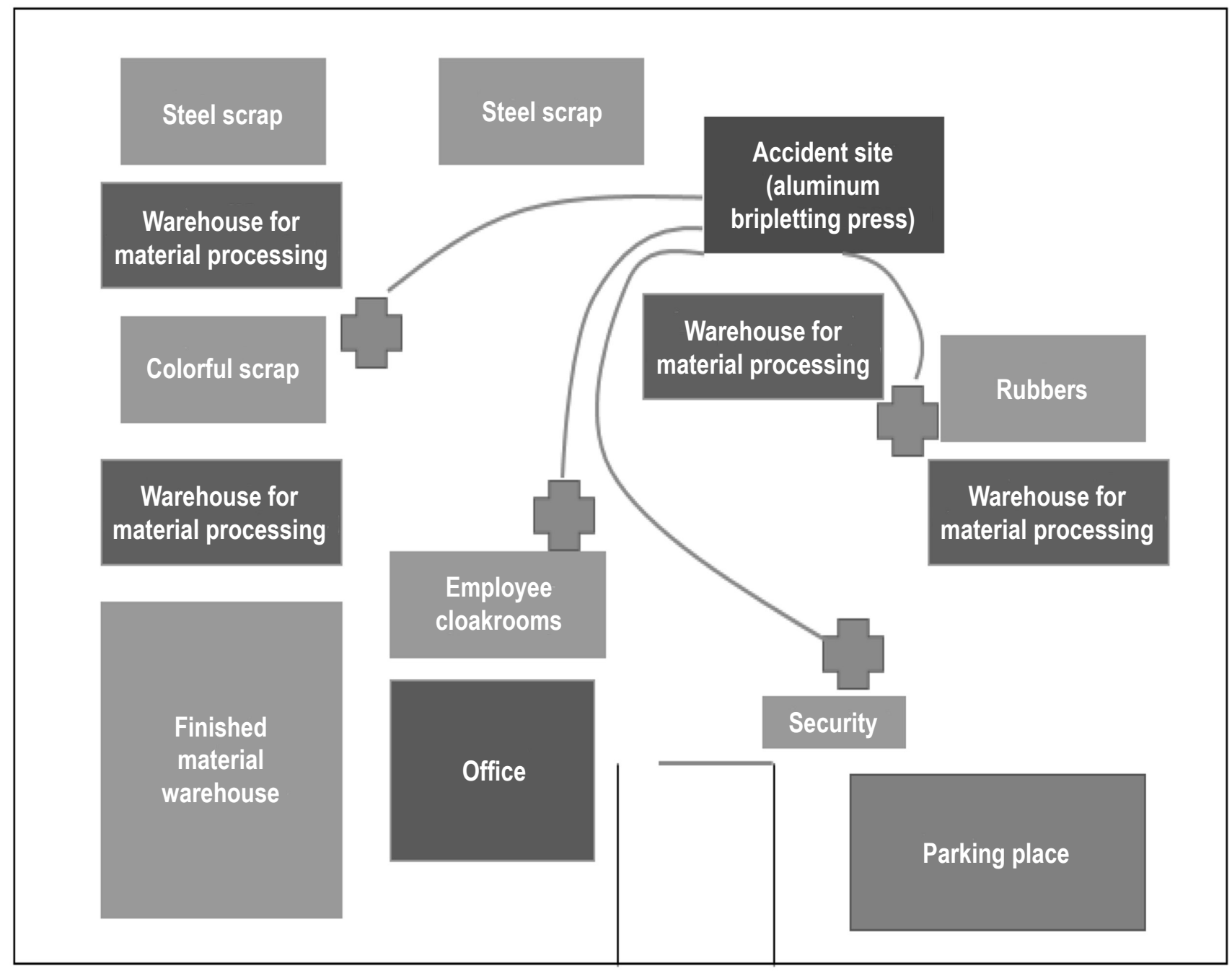

Figure 6. Spaghetti Diagram - the injured party's path from the scene of the incident to first aid points located on the premises of the company. 


\section{Conclusion}

According to Art. 207 of the Labor Code Art. $207 \S 1$. The employer is responsible for the health and safety at work in the workplace (...) $\S 2$. The employer is obliged to protect the health and life of employees by ensuring safe and hygienic working conditions with the appropriate use of science and technology. In particular, the employer is obliged, inter alia, to:

- organize work in a way that ensures safe and hygienic working conditions,

- ensure regulations and safety rules and occupational hygiene are complied with in the workplace, issue orders to remedy deficiencies in this regard and control the implementation of these orders,

- respond to the needs in terms of ensuring occupational health and safety and adapt measures taken to improve the existing level of protection of the health and life of employees, taking into account the changing conditions of work performance,

- ensure the development of a coherent policy to prevent accidents at work and occupational diseases, taking into account technical issues, work organization, working conditions, social relations and the influence of working environment factors.

The analysis of the accident incident showed weaknesses in the aspect of safety and occupational hygiene. By making an analysis according to the Spaghetti diagram, the employer equipped the workplace with a specially marked first aid area. Among other things, such activities support the management of occupational health and safety in the enterprise.

\section{References:}

Bernardi, A. 2019. The capability approach and organizational climate as tools to study occupational health and safety. Insights into Regional Development, 1(2), 155-169. https://doi.org/10.9770/ird.2019.1.2(6)

Central Institute for labor protection http://www.ciop.pl/CIOPPortalWAR/appmanager/ciop/pl?_nfpb=true\&_pageLabel $=$ P2800184421335513641054 (access: 15.09.2021).

Dankiewicz, R., Ostrowska-Dankiewicz, A., Bulut, C. (2020). The attitudes of entrepreneurs of the small and medium-sized enterprises sector in Poland to key business risks. Equilibrium. Quarterly Journal of Economics and Economic Policy, $15(3), 512$.

Główczyńska-Woelke K. 2009. Ocena ryzyka zawodowego (Risk assessment), Warszawa.

Konstytucja Rzeczypospolitej Polskiej z dnia 2 kwietnia 1997 r. (Dz.U. 1997 nr 78 poz. 483). (The Constitution of the Republic of Poland of April 2, 1997 (Journal of Laws of 1997, No. 78, item 483).

Rozporządzenie Rady Ministrów z dnia 1.07.2009 r. w sprawie ustalania okoliczności i przyczyn wypadków przy pracy (Dz.U. z 2009 r. nr 105, poz. 870) (Regulation of the Council of Ministers of 1 July 2009 on determining the circumstances and causes of accidents at work (Journal of Laws of 2009, No. 105, item 870

Studenski R. 1996. Organizacja bezpiecznej pracy w przedsiębiorstwie, (Organization of safe work in the enterprise) Gliwice 1996.

Ustawa z dnia 26 czerwca 1974 r. Kodeks pracy ( Dz. U. z 2020 r. poz. 1320 z późn. zm.). (The Act of June 26, 1974, the Labor Code (Journal of Laws of 2020, item 1320, as amended).

Ustawa z dnia 30 października 2002 r. o ubezpieczeniu społecznym z tytułu wypadków przy pracy i chorób zawodowych (Dz. U. nr 199, poz. 1673, z późn. zm.) (The Act of 30 October 2002 on social insurance against accidents at work and occupational diseases (Journal of Laws No. 199, item 1673, as amended).

Woźny A. 2020. Bezpieczeństwo w środowisku pracy jako dziedzina badań i zarzadzania bezpieczeństwem [in:] Badania nad bezpieczeństwem. Wybrane aspekty, (Safety in the work environment as a field of research and safety management [in:] Safety research. Selected aspects) red. M. Jurgilewicz, K. Michalski, W. Krztoń, Rzeszów 2020.

Woźny A., Dobosz M. 2015. Podstawowa dokumentacja służb BHP, (Basic documentation of OHS services), Rzeszów.

Woźny A., Pacana A., Dobosz M., Saja P. 2015. Bezpieczna praca determinantem jakości i wydajności organizacji, (Safe work is a determinant of the quality and efficiency of the organization). Humanities and Social Sciences HSS, 20(3), 190-194.

Woźny A., Pacana A. 2017. Synthetische Auffassung der Methoden für Gefährdungsbeurteilung, Friedrichshafen. 
Woźny A., Saja P., Dobosz M. 2018. Wpływ metody „, 5 minut dla bezpieczeństwa” na kulturę BHP w przedsiębiorstwie [w:] Quality, Production, Improvement. Bezpieczeństwo, Jakość, Zarzadzanie (The impact of the "5 minutes for safety" method on the health and safety culture in the enterprise [in:] Quality, Production, Improvement. Security, Quality, Management) R. Ulewicz, M. Ingaldi (red.), Częstochowa.

Woźny A., Saja P. 2019. Dobosz M., Zapobieganie błędom w procedurze powypadkowej z wykorzystaniem diagramu przyczynowo-skutkowego Ishikawy [In:] Praktyczne aspekty zarzadzania produkcja i bezpieczeństwem (Preventing errors in the post-accident procedure using the Ishikawa cause-and-effect diagram [in:] Practical aspects of production and safety management) red. R. Ulewicz, R. Dwornicka, Kraków.

Artur WOŹNY is the Professor at the Rzeszów University of Technology, PL. Research interests: internal security, health and safety, safety management.

ORCID ID: 0000-0002-0294-0157

Michał KOŚCIÓடEK is an assistant at the Rzeszów University of Technology, PL. Research interests: safety management. ORCID ID: 0000-0002-4059-9244

Anna OSTROWSKA-DANKIEWICZ is the Professor at the Rzeszów University of Technology, PL. Research interests: safety management.

ORCID ID: 0000-0002-2131-4522

Piotr SAJA health and safety inspector cooperating with several dozen companies from various industries, PL. Research interests: health and safety, safety management.

ORCID ID: 0000-0002-8607-9455 